\title{
As capitais no palco: teatro e sociedade na Europa oitocentista
}

\author{
Fernando Santos Berçot \\ Universidade Federal do Rio de Janeiro \\ Rio de Janeiro, RJ, Brasil \\ fbercot@hotmail.com
}

Charle, Christophe. A gênese da sociedade do espetáculo: teatro em Paris, Berlim, Londres e Viena. Tradução de Hildegard Feist. São Paulo: Companhia das Letras, 2012.

O barão de Gondremarck, nobre sueco que visita a capital francesa em La vie parisienne, traz consigo a expectativa de um deleite impossível de se consumar em outro lugar. Ele sonha com um mundo dominado pelos prazeres da carne, e deseja ardentemente um rendez-vous com uma bela anfitriá, mas acaba ludibriado por um homem sedutor, o visconde de Gardefeu, que o expóe a situaçôes ridículas para livrar-se dele e aproveitar alguns momentos de intimidade com a bela esposa do estrangeiro. Com um enredo repleto de situações inusitadas, a opereta de Henri Meilhac e Ludovic Havévy, musicada por Jacques Offenbach e estreada no Palais Royal em 1866, obteve um estrondoso sucesso desde a primeira representação. Aos olhos de um público ávido por divertimento, esse retrato jocoso da sociedade francesa, povoada de personagens matreiros e tipos libertinos, podia tornar-se mais picante quando contrastado com os costumes estrangeiros ou provincianos. Para os turistas que chegavam à cidade para a Exposição Universal, evento que reunia as últimas novidades de arte e ciência sob os auspícios de Napoleão III, a peça se convertia em uma das grandes atraçóes do momento, um divertido apanhado de plaisanteries digno dos padróes franceses, numa época em que a "moderna Babilônia" exportava seus modelos para todo o continente.

La vie parisienne está entre as obras mais representativas de um teatro zombeteiro e pou- co comedido, mas muito apreciado pela plateia heterogênea das capitais europeias na década de 1860, que testemunhava o advento de uma primeira sociedade do espetáculo, objeto de análise de Christophe Charle em A gênese da sociedade do espetáculo. Nesse estudo de história social comparada, o autor investiga a trajetória teatral de quatro capitais europeias (Londres, Paris, Viena e Berlim), buscando os fundamentos da transformação que afetou as estruturas do universo teatral, com seus cânones e normas, permitindo o surgimento de gêneros mistos que, tal como a opereta, eram criados sob medida para um público mais amplo. As quatro cidades selecionadas por Charle, que estavam entre os centros urbanos mais populosos da Europa ocidental durante o Oitocentos, contavam com uma tradiçáo teatral já bastante estabelecida e desempenhavam um papel de difusão cultural em escala regional, ou mesmo continental.

O processo descrito pelo autor pode ser sintetizado em poucas palavras: o crescimento das cidades e a diversificação do público ao longo do Oitocentos geram uma maior demanda por espetáculos. A consequente ampliação do parque teatral das capitais, por sua vez, faz crescer o número dos artistas empregados, e a maior oferta de gêneros torna necessária a adoção de estratégias comerciais e simbólicas por parte das companhias, além de criar um mercado bastante lucrativo para os autores mais dispostos a produzir dramas e comédias voltados para o público médio. Esse processo é acompanhado por uma lenta e paulatina liberalização da atividade teatral nas quatro cidades. As barreiras que limi- 
tavam a abertura de novos teatros e a formação de companhias de atores desaparecem ao longo da segunda metade do século XIX, cedendo espaço ao regime de livre empresa. As consequências dessas transformaçôes, contudo, serão sentidas de modos diferentes em cada uma das capitais elencadas por Charle.

Não chega a admirar que essa proposta teórica implique um estudo comparativo da geografia social de cada cidade, capaz de identificar a localização dos principais teatros e o público a que estavam destinados, e que as transformaçôes desse mesmo público e das companhias não passem despercebidas numa abordagem que se pretende abrangente. Com efeito, o autor faz um verdadeiro inventário do universo teatral das quatro capitais, e os dados levantados mostram a capacidade das salas, o número de artistas empregados em cada cidade, o salário e a instrução média dos atores em atividade ao longo do século. Assim, em toda a primeira parte da obra, o leitor se vê diante de uma argumentação crivada de estatísticas e de quadros comparativos, resultados de um minucioso trabalho de compilação arquivística que serve de suporte para a análise socio-histórica que se realiza em seguida. Essa, por sua vez, está calcada em uma amostragem variada das peças que mais impactaram o público, tornando possível um juízo seguro sobre as condiçóes de possibilidade desses sucessos e as diferentes estratégias adotadas pelos autores que disputavam os aplausos da plateia e os louros de um sucesso quase sempre efêmero.

$\mathrm{Na}$ raiz desse método de análise está a crítica a muitos trabalhos consagrados no campo da história literária, que se limitam ao estudo do texto teatral e dos dramaturgos mais célebres, sem atentar para a dinâmica multifacetada das práticas teatrais que unem autores, atores e público num coletivo tripartite e indivisível, e que se reinventa a cada apresentação, em cada teatro, em cada contexto político ou social. Charle quer contornar o anedótico, evitando as generalizaçóes e a parcialidade de que padecem, segundo ele, a maioria das obras já publicadas sobre o tema. Daí o uso de estatísticas e o estudo atento dos casos mais representativos. Mas é também em nome da qualidade de sua própria análise que o autor confessa os limites deste mesmo projeto. Ao priorizar o exame dos autores parisienses, que lhe são mais familiares, Charle abdica em grande parte do viés comparativo que havia proposto, limitando-se a apresentar como contraste um panorama apenas esboçado do repertório encenado nas outras três capitais.

Em Paris, esse teatro dos bulevares encena a comédia de um equilíbrio social em constante transformação nas últimas décadas do século. Variando conforme as posiçóes políticas de seus autores e sua inserção no campo literário, as obras que sobem ao palco ora escarnecem dos novos ricos e de suas tolas pretensóes, ora denunciam a ambição dos homens de negócio; ora enveredam pelos caminhos oblíquos do drama social, ora enaltecem as virtudes burguesas que se levantam contra o ranço aristocrático do Romantismo e da Restauração. Essa primeira sociedade do espetáculo, explica-nos Charle, se consolida em meio a disputas de toda espécie, que coexistem no hiato entre a sociedade imaginária dos palcos e a sociedade real da plateia, e ainda opóem os interesses dos atores aos dos dramaturgos; as perspectivas de realização desses últimos à cupidez dos empresários; os preconceitos do parterre às transgressóes dos autores mais polêmicos em matéria de moral, política e religião. A representação teatral transforma o texto escrito ao confrontá-lo com os pudores do coletivo, como adverte Jules Claretie. Nem sempre o que pode ser lido e publicado livremente é autorizado a subir à cena.

A liberalização transformou o teatro em indústria e reduziu o papel do financiamento estatal das salas, sem o qual os empreendimentos mais antigos náo eram capazes de prosperar. Charle demonstra que o negócio teatral ganhava em dinamismo à medida que se tornavam complexas as redes de contato e as amizades literárias dos salóes, cada vez mais imprescindíveis para o êxito de uma peça. Era o tempo das grandes parcerias entre comediógrafos, das traduçóes de sucessos estrangeiros, dos plágios e adaptaçóes livres que precederam a consolidação dos direitos do autor. 
Pouco a pouco, as restriçóes à atividade teatral tornavam-se mais brandas, e uma aplicação mais flexível das normas concernentes aos espetáculos começava a tornar possíveis certas ousadias até então vetadas pelas autoridades.

É interessante notar, porém, que o movimento que conduziu a essa maior liberdade não foi um processo contínuo, sem retrocessos. Foi mais precoce em Paris do que nos estados alemáes, mas mesmo na capital francesa teve de ceder reiteradas vezes ao conservadorismo de parte do público, às diretivas de uma censura mais ou menos severa, que só desaparece por completo no século $\mathrm{XX}$, e ao receio constante dos proprietários de salas e dos diretores de companhias, preocupados com o retorno de seus investimentos e com os possíveis prejuízos advindos de um escândalo público. Temor que se intensifica quando o teatro se transforma em tribuna, num palanque onde se alternam, sob o manto do desprezo ou do enaltecimento, personagens que encarnam as tendências políticas dominantes ou minoritárias do momento. E, no plano social, o juízo do palco e seu veredito recaem sobre os mais diversos personagens do cenário urbano: feministas e operários, monarquistas e líderes sindicais, judeus e negociantes ricos invadem a cena com seus discursos conflitantes.

Se as disparidades entre as classes e o embate entre as geraçóes permanecem temas delicados, querelas de toda espécie estão agora na ordem do dia, quer nas comic operas de Gilbert e Sullivan, quer nas pièces bien faites de Victorien Sardou e seus imitadores, ainda que o grau de ferocidade das contendas representadas tenha de ser diluído em favor do divertimento do público, que quase sempre se satisfaz com a reconciliação das partes em conflito. Assim, a autocensura dos dramaturgos e dos diretores poupa ao censor uma parte de seu trabalho preventivo, e os experimentos mais radicais de contestação política e social ficam reservados aos palcos marginais, refúgios da vanguarda, e às sociedades de encenação privada, que escapam à legislação reguladora dos espetáculos públicos.

Os números apresentados por Charle mostram ao leitor um público em franco crescimento, que incorpora ao longo do século parcelas um pouco menos privilegiadas da população, as quais se somam à antiga nobreza e aos homens de negócio, aos literatos bem nascidos e aos frequentadores dos salóes. Em suma, a toda essa boa sociedade que habita os bairros nobres da Londres vitoriana ou da Viena dos Strauss, e que às margens do Sena ganha o tom mais mundano do Tout-Paris dos jornalistas. Se a audiência das salas é bastante heterogênea, e inclui burgueses e funcionários públicos, nobres e estudantes, o objetivo de agradar a todos se torna uma tarefa das mais complexas, que exige medidas exatas de cautela e de ousadia por parte dos protagonistas desse meio teatral transformado, sejam eles artistas, empresários ou autores.

Em que pesem as reservas feitas ao pudor do público, as controvérsias morais e políticas são muito frequentes nesses "templos do divertimento", de maneira que o panorama do repertório teatral proposto por Charle não pode prescindir de uma análise dos grandes escândalos, que não poupam nem mesmo os autores mais caros ao público. Se o antissemitismo faz suas vítimas nos palcos vienenses, são as referências à política e à situação do operariado que despertam a sanha dos censores em Berlim, mas as proibiçóes são feitas em nome do decoro público. Temas como o adultério e a prostituição tornam-se cada vez mais costumeiros, ainda que encontrem a resistência de uma parte da plateia, predisposta a considerar vulgares as alusóes eróticas e os diálogos picantes. Charle explora as reaçóes de um público dividido entre o entusiasmo e a indignação, e parece reforçar a cada página as impressóes de Émile Bayard, que retrata o misto de repulsa, aprovação e euforia na audiência dos Bouffes-Parisiens em uma de suas caricaturas da década de 1860.

Análises de grande abrangência, como a empreendida em $A$ gênese da sociedade do espetáculo, tornaram-se marcas da produção de Christophe Charle em seus mais de trinta anos de carreira. Professor de história contemporânea na Universidade de Paris I, o historiador já se dispôs a traçar em poucas páginas os principais aspectos da sociedade francesa do Oitocentos, dedicando-se ainda 
à cultura parisiense no fin de siècle e à história da imprensa na França entre a monarquia de Julho e o período entreguerras, em obras ainda inéditas no Brasil (CHARLE, Christophe. Histoire sociale de la France au XIXe siècle. Paris: Éditions du Seuil, 1991; Paris fin de siècle: culture et politique. Paris: Éditions du Seuil, 1998; Le siècle de la presse (1830-1939). Paris: Éditions du Seuil, 2004). Ao abordar o teatro e o seu público, o autor revisita um tema que já habita o seu horizonte investigativo desde o doutorado, na década de 1970. Sua adesão ao vocabulário sociológico de Pierre Bourdieu, de quem foi aluno, e às categorias da nova história social leva-o a rejeitar o famoso estudo de Guy Debord (A sociedade do espetáculo. Rio de Janeiro: Contraponto, 1997) como um "engenhoso patchwork ideológico", mas não o impede de incorporar as análises quantitativas e os aportes da história econômica à metodologia que dá suporte a seu próprio texto.

Charle está ciente, porém, do alcance limitado de sua análise comparativa. Mesmo para o caso parisiense, o autor náo parece ter a pretensão de esgotar o tema proposto, nem poderia fazê-lo. O leitor, por sua vez, depois de seguir por várias páginas os sucessos e fracassos das estreias mais importantes nos palcos parisienses da Terceira República, depara-se com um pós-escrito pouco conclusivo, uma espécie de epílogo que aponta os paralelismos entre a primeira sociedade do espetáculo e sua sucessora no século XX. O cinema, com efeito, também se transforma em indústria, cativando um público ainda mais numeroso que o dos teatros. Como nos lembra o autor, os primeiros cineastas adaptam para as telas de projeção os mesmos tipos de melodramas e vaudevilles que já haviam feito a fortuna dos empresários teatrais. Ao fazê-lo, apropriam-se de fórmulas já testadas nos palcos desde o século anterior, época em que as salas de espetáculos logravam atrair um numeroso concurso de espectadores que se deleitavam com o riso fácil das farsas, com as intrigas familiares de final feliz ou com os corpos voluptuosos das "atrizinhas" em seus números de dança, que seduziam o barão de Gondremarck em sua cômica e desastrosa aventura parisiense:

Quanto a mim, quero ver os teatros,

Não esses onde se aborrece, mas

Esses onde atrizes ligeiras

Oferecem aos olhares mil atrativos. 